\title{
Intellectual Capital Management Model for Competitiveness in a Beach Hotel: Case Study in the City of Manzanillo, Colima
}

\section{Modelo de Gestión del Capital Intelectual para la Competitividad en un Hotel de Playa: Estudio de Caso en la Ciudad de Manzanillo, Colima}

\author{
LINO-GAMIÑO, Juan Alfredo*†, BARRAGÁN-VÁZQUEZ, Carlos Hugo, LÓPEZ-JIMÉNEZ, Sergio \\ Felipe and CHANG MUÑOZ, Eduardo
}

\section{Universidad de Colima \\ Universidad de la Costa}

ID $1^{\text {st }}$ Autor: Juan Alfredo, Lino-Gamiño / ORC ID: 0000-0002-7022-5438, CVU CONACYT ID: 268945

ID $1^{\text {st }}$ Coautor: Carlos Hugo, Barragán-Vázquez / ORC ID: 0000-0003-3796-1326

ID $2^{\text {nd }}$ Coautor Sergio Felipe, López-Jiménez / ORC ID: 0000-0001-6524-8435, CVU CONACYT ID: 268955

ID $3^{\text {rd }}$ Coautor Eduardo, Chang Muñoz / ORC ID: 0000-0002-1826-1626

DOI: $10.35429 / J M P C .2019 .15 .5 .22 .38$

Recibido March 26, 2019; Aceptado June 28, 2019

\begin{abstract}
For decades the economy was based on production and physical assets were the main source of resources. This situation has now changed, with intangible assets now being the main source of value creation and sustainability of competitive advantages in the company. The current definition of intangibles has focused on the strategic area within the Resource-Based Approach, emerging as a complementary structure to the Competitive Advantage approach. Goals: The analysis of intangibles as a scenario of competitiveness in the hotel industry, in particular, such as management, control and identification of unspecified intangibles. Metodology: Starting from the general objective, this research will have a mixed, quantitative and qualitative methodological approach. And through a quantitative research approach of analytical type, it is intended to know the influence of intangible resources on the factors that allow obtaining and sustaining a competitive advantage in the company. The above is based on the "Intellectus Model" (IADE-CIC, 2003) and the "Five Capital Model" (IADE-Caja Madrid, 2004). Contributios: Based on 106 variables analyzed, the multifactorial analysis by reduction of factors allows to determine 11 cross factors that contribute to generate the space of the intangible assets that in the case of the hotel which allows to be more competitive.
\end{abstract}

Intangibles, Competitiveness, Processes

\begin{abstract}
Resumen
Durante décadas la economía estuvo basada en la producción y los activos físicos constituyeron la principal fuente generadora de recursos. Esta situación ha cambiado actualmente, siendo ahora los activos intangibles la fuente principal de creación de valor y sustentabilidad de ventajas competitivas en la empresa. La definición actual de los intangibles se ha centrado en el ámbito estratégico dentro del Enfoque Basado en los Recursos, surgiendo como estructura complementaria al enfoque de la Ventaja Competitiva.Objetivos: El análisis de intangibles como un escenario de competitividad en la industria hotelera, caso en particular, como son gestión, control e identificación de intangibles no determinados. Metodología: Partiendo del objetivo general, la presente investigación tendrá un enfoque metodológico mixto, cuantitativo y cualitativo. Y a través de un enfoque de investigación cuantitativo de tipo analítico, se pretende conocer la influencia de los recursos intangible sobre los factores que permiten obtener y sostener una ventaja competitiva en la empresa. Lo anterior tomado como base el "Modelo Intellectus" (IADE-CIC, 2003) y el "Modelo de los Cinco Capitales" (IADE-Caja Madrid, 2004). Contribución: De las 106 variables analizadas el análisis multifactorial por reducción de factores permite determinar 31 items cruzados que contribuyen a generar el espacio de los activos intangibles que para el caso del hotel lo que permite ser más competitivo.
\end{abstract}

Intangibles, Competitividad, Procesos

Citation: LINO-GAMIÑO, Juan Alfredo, BARRAGÁN-VÁZQUEZ, Carlos Hugo, LÓPEZ-JIMÉNEZ, Sergio Felipe and CHANG MUÑOZ, Eduardo. Intellectual Capital Management Model for Competitiveness in a Beach Hotel: Case Study in the City of Manzanillo, Colima. Journal of Microfinance Planning and Control. 2019, 5-15: 22-38

\footnotetext{
* Correspondence to Author (email: jlino@ucol.mx)

$\dagger$ Researcher contributing first author.
} 


\section{Introduction}

For decades the economy was based on production and physical assets were the main source of resources. This situation has now changed, with intangible assets now being the main source of value creation and sustainability of competitive advantages in the company.

Nowadays companies face a new era of the economy based on knowledge and learning, which has been called the knowledge society (Lane, 1966; Well, 1998; Gallardo, 2001). This paradigm shift is observed today, so that the passage of tangible resources has ceded its present role in the value chain to intangibles making knowledge management necessary. As Bueno (1998) and Raich (2000) point out, this transition created the need to manage the company as a whole and generated new concepts, such as knowledge management, intellectual capital and even human capital, however, it is not yet has developed a method to measure intellectual capital or human capital in monetary terms.

The current definition of intangibles has focused on the strategic scope within the Resource-Based Approach, emerging as a complementary structure to the Competitive Advantage approach, which raises the construction of an advantageous and sustainable competitive position in the long term, through a position in the product market (Porter, 1985). However, the Resource-Based Approach assumes a refreshing vision of strategic conception, since it considers the importance of internal factors (resources and capabilities) as the foundation of the organizational strategy, therefore, of the competitive position.

The first contributions in this approach were those of Grant (1991), Barney (1991) and Peteraf (1993). Although there are other important contributions such as those of Wernerfelt (1984), Aaker (1989), Dierickx and Cool (1989), Amit and Shoemaker (1993) among others. In the Spanish sphere are those of Fernández (1993) and Fernández and Suarez (1996).
With this new strategic approach and a changing and globalized environment where knowledge and information become important, intangible assets are instituted as those strategic resources that meet the necessary characteristics to generate sustainable competitive advantage through characteristics such as heterogeneity, value relevance, shortage, imperfect mobility, durability, inimitability and imperfect substitutability (Grant, 1991; Barney, 1991; Peteraf, 1993). Therefore, the efficient management of intangibles has become the main source of the competitive advantage of companies.

However, despite the importance of the intangible Gallardo and Pérez (2003), they state that there is a great difficulty, referring to their valuation, since accounting does not accurately reflect the true value of the company, that is, part of the Intangible source value is not reflected in the financial statements. Years ago, factors such as labor, land and capital were identified as drivers of performance obtained by companies, now the vision has changed radically, passing the aforementioned elements to the background and reaching factors of intangible nature.

Cañibano, García-Ayuso and Sánchez (1999) explain that efficient strategic management must rely on quantitative and qualitative information on intangible assets, being essential to design and implement an information system that considers the existence and relevance of such intangibles. Intangible assets differ from financial and physical resources in the sense that their value depends on how well they serve the organization. Although, this prevents an independent valuation of intangible assets, so a completely different approach is required to assess their value.

One of the main aspects in the framework of business management is to know the effect of intangibles on the performance of the company. Those companies that manage to transfer their strategy to measurement systems will be able to effectively execute their strategy, since they will be able to communicate their objectives and goals. This communication makes managers and employees focus on critical inducers, allowing them to align and link investments, initiatives and actions with the achievement of strategic objectives (Cañibano, García-Ayuso and Sánchez, 1999). 
The main purpose of this work is to develop an intellectual capital management model for the generation of sustainable competitive advantage through a case study in a beach hotel in the city of Manzanillo Colima.

\section{Emergence of knowledge-based society}

In pre-industrial society, the labor force was overwhelmingly employed in extractive industries, such as mining, fishing, forestry, agriculture, etc. It worked with a brute muscular force, using traditional methods and with greater dependence on natural elements. Therefore, productivity was low and the economy was subject to tangible events and price fluctuations in raw materials. These societies were agrarian and structured with traditional forms of routine and authority.

Already in the industrial era the world becomes technical and rationalized. The machine predominates and electrical energy replaces muscular strength, providing the necessary boost for productivity, that is, doing more with less. In this era new transformations arise with respect to the elementary force in a company: the human element. The knowledge of the trade is divided into its most basic components and the craftsman is replaced by new elements: the engineer, who becomes responsible for the layout and flow of work and the semi-specialized worker, who becomes the human gear between the machines (Bell, 1976).

Thus, a world of coordination, planning and programming is born, where the human element, inputs and markets are assembled for the production and distribution of goods. The components of the goods are produced jointly in the precise time and the adequate proportion to accelerate the flow of said goods. In this way a necessary distinction is introduced between the role and the person, which is formalized in a company organization chart. The criterion of the technique is efficiency and the way of life is modeled on the economy, focusing on how to extract the greatest amount of energy from a unit provided by nature, such as coal, oil, gas, etc., using the best machines and getting competitive prices.

A new stage arises in the industrial era, the post-industrial, based on services. Now what counts is not brute force or energy, but information.
The key piece in the company is the trained and trained professional to provide the types of specialization. The industrial society was characterized by the amount of goods that indicated the standard of living, now the postindustrial society is characterized by the quality of life provided by services and amenities, such as health, education, entertainment and the arts.

According to Bell (1976), it was in the second half of the twentieth century that there has been an extension of the specialization of functions from the economic to the intellectual field. It is at this time when the knowledge society is born. Basically the proposal of the idea of a society dedicated to knowledge was made by Robert Lane (1966) who presents an approximation to that definition, mentioning that it is the one in which, to a greater degree than in other societies, its members:

1. They investigate the basis of their beliefs about man, nature and society.

2. They are guided, possibly unconsciously, by objective verification standards and with respect to higher education follow scientific rules of verification and deduction in research.

3. They devote considerable amounts of resources to research, thus counting on a broad pool of knowledge.

4. They accumulate, organize and interpret knowledge in a constant effort to achieve consequences of immediate utility.

5. They use this knowledge to guide and perhaps modify the values and goals, as well as to advance them.

Since then, a set of ideas, concepts and expressions that model its true content and its real reach in the scientific community have emerged and becoming widely disseminated, among other expressions those of human capital, intellectual capital, intangible assets, learning process, organization smart, organizational learning, explicit knowledge, tacit knowledge, knowledge economy and knowledge management (Well, 1998).

The knowledge society has been characterized by the constant emergence of new knowledge, by the permanent development of intellectual faculties, all this being specified, in an unusual acceleration of the expiration of dominant paradigms, of the obsolescence of the methods of analysis. 
Bueno (1998) argues that currently in society theoretical knowledge and tacit knowledge are becoming important over any other kind of knowledge, taking more relevance those that require a certain mental model and processes based on creation, ideas, and abstraction and innovation. In particular, tacit knowledge is what enables the generation and sustainability of the competitive business advantage in the current economy (Nonaka and Takeouchi, 1995).

\section{Transformation of information into knowledge}

Within the creation of the knowledge society, the transformation of the data or information to what we know today as Knowledge, a process that leads to the formation of the concept of Distinctive Basic Competence (Well, 1998: 215).

The evolution that knowledge has had consists of three stages:

1. The data process. Use of technologies that transform this data into information.

2. Learning process. At this stage the information is converted into knowledge, through the learning process, that is, how to learn to learn to learn new knowledge.

3. Distinctive competence. At this stage, knowledge is transformed into distinctive competence, that is, knowing how to do better than others, thanks to a certain process of mental creation.

This process seeks to produce and disseminate knowledge, disseminate human talent or intelligence, both individual and organizational throughout the structure of the company. Thanks to this process, the company has an immense flow of knowledge that can be released, provided it is able to properly manage the flows of such knowledge that circulate through it. Management that aims to generate new knowledge that allows it to not only create competitive advantage or distinctive competence, but also make it more durable. The knowledge society depends largely on the ability of the company to learn, how knowledge and innovative talent are incorporated both in people and in the company.
Taking reference to Bueno (1998) classifies knowledge as:

a) Knowledge gained: is the knowledge coming from outside the company and that is acquired through contracts, both perfect and imperfect. This knowledge is explicit for the company.

b) Knowledge created: it is the knowledge that is born inside the company and that can both focus on explicit knowledge and tacit knowledge.

c) Explicit knowledge: is the knowledge that can be transmitted or shared between people or within the organization with relative ease.

d) Tacit knowledge: it is the knowledge that presents certain difficulty and complexity to be transmitted or communicated interpersonally.

Following the previous author, it is explained that both explicit and tacit knowledge can act as an origin in the creation of new knowledge. Explicit knowledge is basically composed of technical knowledge, some skills or abilities and few attitudes, which allows it to be easily transmitted through current information and communication technologies. While tacit knowledge is closer to talent, art or a certain mental model, aspects that are difficult to convey interpersonally, basically composed of attitudes, capacities and certain abstract, complex and sophisticated knowledge.

Of the concrete combinations that arise from this knowledge, you have to:

1 The generation of explicit knowledge from explicit knowledge is done through processes or systems.

2 Based on explicit knowledge, you can create tacit knowledge or know-how in the company, this takes the name of tacit knowledge in people. This type of knowledge involves internalizing certain patterns or patterns of action and carrying out specific learning processes.

3 If tacit knowledge is transformed into explicit knowledge, that is, if they are externalized, we would be talking about concepts such as business strategy. 
If tacit knowledge generates new tacit knowledge, it will have been possible to socialize and share among all members of the organization, new values and attitudes, aspects that will make them different and will improve their competitiveness.

To understand the concept we know today of knowledge it is convenient to try to understand its definition, consulting the following authors. Bell (1976: 206) defines it as "a set of organized expositions of ideas, presenting a reasoned trial or an experimental result, which is transmitted to others through some means of communication in a systematic way".

Nonaka and Takeouchi (1995) mention that knowledge is a justified certainty, that is, an individual justifies the truthfulness of his certainties based on observations of the world around him; These observations depend on a point of view, personal sensitivity and individual experience. Therefore, when an individual creates knowledge, it makes sense of a new situation with the justified certainties that he has firmly adopted.

After knowing the transformation that the information has had in knowledge and its conceptualization, it is necessary to highlight the challenge that companies face with respect to the efficient use of the knowledge of their workers and the way in which they can be used in the construction of sustainable competitive advantages.

In the opinion of Gallardo and Pérez (2003), they are living in a society in which theoretical and tacit knowledge are gaining enormous importance over any other kind of knowledge. And it is this type of knowledge that motivates the generation and sustainability of competitive business advantages. Gallardo and Calamonte del Río (2002) indicate the need to have a human potential capable of competing in the market, capable of achieving competitive or distinctive advantages, which uncheck the company from the rest of the sector, since it is a verifiable fact that training of employees is a transcendent element for the supervision and expansion of the company in the current era.

In general, the possible changes will be manifested in the line of knowledge management.
This means giving greater importance to intangible resources over tangibles, a circumstance that was not previously occurring.

If in today's society the new challenge is the construction of the knowledge economy paradigm, in the company that challenge is translated by the way in which this knowledge will be managed. This undoubtedly represents an arduous, complex and emerging task. It is said that it will be arduous, because it must try to release accumulated mental energy in the organization, enclosed in the minds of the people who compose it. It is complex, since knowing how to convert this intellect into a business asset, into organizational knowledge, which can be accessed by all people in the company, so that it can be used in the creation of new knowledge. Emerging, because it is born with its own principles.

Therefore, Knowledge Management is a strategy to be considered by companies whose objective will be to create greater value for the shareholder and those involved in the development of the organization such as: customers, employees, suppliers, creditors. This strategy will be undertaken, first, by capturing individual talent as an organizational and secondly, developing it further and trying to retain it within the organization to give its greatest benefits. It is clear that, if the company outsources a strategy to its market, in proportion, it must carry out an internal strategy, which allows it to manage the knowledge flows that circulate and develop within it.

In this sense, Raich (2000) points out that companies should be able to manage in an organization the tangible, intangible, virtual parts and therefore knowledge. Knowledge depends on the ability of people and organizations to learn and how they incorporate knowledge and innovation. Gallardo and Roldán (2003) point out that this has resulted in the processes integrated in the so-called Knowledge Management, referred to as the creation and proper application of knowledge in companies, being necessary to contemplate new strategies that include knowledge as a fundamental element.

Knowledge within the company can be located at different levels: in its workers and managers, in its suppliers, in relations with other companies, in its customers, etc. 
To identify this knowledge, it is convenient to use the different groups named under the concept of Intellectual Capital and that are not fully captured in the balance sheet (Sánchez, Chaminade and Escobar, 1999). Some authors affirm that the organization's resources are essential when they allow the company to develop strategies that achieve and sustain a competitive advantage. One of those resources is knowledge, a competitive resource that the company has (Nonaka and Takeouchi, 1995; Grant, 1996).

The value of employee knowledge depends directly on its potential to contribute to the achievement and maintenance of the competitive advantage of the company. Some research in this regard (Huselid, 1995; Pennings, Lee and Van Witteloostujin, 1998), present attributes of human resources, including training, experience, skills and in particular, the characteristics of managers, influencing the results of the company. Ordonez (2005) mentions that even using such knowledge and considered as an important factor in the current competitive environment, it is not enough to use the knowledge base of employees.

Although the company's resources and capabilities have added value in the past, changes in consumer demands, in the structure of industry or in technology, can make them less valuable in the future (Barney, $1995: 51$ )

\section{The resource-based approach}

During the 1980s, the intensity and increasing dynamism of competitiveness through product markets has had profound implications for the evolution of strategic thinking in companies. The external environment in companies has focused attention on resources and capabilities as the main source of sustainable competitive advantage and the main parameter for the formulation of strategies (Ordonez, 2003).

However, the resources themselves do not reveal the competitive advantage, but that this would be determined by the way in which they are exploited as a whole, therefore, the role played by the capabilities or competencies in the company must also be considered. (Cruz, 2002).
In the 1990s the analysis of the strategies focused on the industrial structure, that is, it was considered that the differences in business results were a consequence of the sector in which the company developed its activity, so there was a greater homogeneity between companies that belonged to the same sector (Porter, 1980, 1985).

On the other hand, Rumelt (1991) demonstrated the existence of greater profitability differences between companies that belonged to the same industry than between companies from different sectors and Cool and Schendel (1988) in a study conducted in the pharmaceutical industry, concluded that there were differences Significant profitability among companies that belonged to the same strategic group.

These verifiable events led to a rethinking of the determinants of income in the company and since then it has been considered as a fundamental basis for the sustainability of a competitive advantage the role of the company's resources and capabilities (Cruz, 2002). So Grant (1991) has come to affirm that a resourcebased perspective is the fundamental basis for business strategy and favorable economic results.

Part of the antecedents of the Theory of Resources and Capabilities are found in the Theory of the Growth of the Company (Penrose, 1962) and in the works on Strategic Management (Andrews, 1987) where the strategy is defined as the adjustment between what the company can do (strengths and weaknesses) and what the environment allows (opportunities and threats).

On the other hand, the theory of the growth of the company (Penrose, 1962) considers the company as an administrative organization with a set of productive, human and material resources. Its approach allows us to visualize that resources are never by themselves, the inputs in productive processes, without the services that resources can provide. The services are the result of experience and knowledge accumulated within the company, and therefore, specific. 
Nelson and Winter (1996), through their Theory of Evolutionary Change, argue that the company can be seen as a repository of knowledge, that is, that it has a specific or specific range of knowledge that it will use in its production process. This range of knowledge, generally with its own characteristics, distinguishes one company from the other, even with the same activities and geographical place of establishment. This knowledge is stored or stored in the company, allowing you to build your own behavior model that can be predictable and regular, becoming what could be called the genes of the organization.

Now, from the approach of the Economic Theory, some explanations have been made to understand the existence of lasting differences between the results of the company (Teece, Pisano, and Shuen, 1997). This theory has been an essential part for the construction of an analysis model of the interrelationships between the strategy and the strategic resources of the company, studying among other aspects the way in which the organizational resources are applied and combined, making the competitive advantage be sustainable, the nature of income generated by resources and the origins of heterogeneity (Ordóñez, 2003).

However, the most relevant antecedent on the perspective of the resource-based company is Wernerfelt's (1984) research, since then there have been many empirical and theoretical investigations that analyze the competitiveness of the resource-based approach and capabilities, to mention a few are: Dierickx and Cool (1989), Grant (1991), Barney (1991), Connor (1991), Schoemaker (1992), Mahoney and Pandian (1992), Hall (1992, 1993), Amit and Schoemaker (1993) and Peteraf (1993).

\section{The company as a set of resources and capabilities}

From the perspective of the Theory of Resources and Capacities, the company is defined as "an organized and unique set of heterogeneous resources and capacities that are generated, developed and improved over time" (Cruz, 2002: 6). As Barney (1991) states that there is a great diversity of companies, even in the same sector, so that heterogeneity is a source of sustainable competitive advantage, which allows explaining the differences in profitability between them.
Peteraf (1993) mentions that the heterogeneity within the theory of resources and capacities is made up of the differences between the results obtained from companies of the same industry, originated by the different levels of efficiency achieved by the heterogeneous resources. The company that possesses a combination of resources and capabilities superior to other companies, will obtain superior results.

Barney (1991) states that an important postulate of the theory of resources and capabilities is that these are heterogeneous among the same companies, that is, the resources that feed the productive process within an industry are distributed in a heterogeneous or diverse way among the companies that integrate it. This characteristic of resources within the same industry is argued by this theory, given the scarcity of superior resources. That is, if the resources were homogeneous, all companies could develop the same strategies and therefore could not achieve differentiation through these resources, not achieving a competitive advantage.

Wernerfelt (1984) points out that the Theory of Resources and Capabilities explains how and why companies achieve a sustainable competitive advantage and are able to maintain it. Its main focus is to consider the company as a set of unique resources of diverse nature, moving away from the traditional economic perspective of analyzing strategies based on their activities in the market.

As stated in previous paragraphs, resources and capabilities have significant relevance in achieving economic benefits of the company. Therefore, it is necessary to consider the definitions and classification of "resources" in order to contextualize this theory.

For Wernerfelt (1984), resources are all those tangible and intangible assets that are linked to the company in a semi-permanent manner, as is the case with brands, own technological knowledge, qualified personnel, commercial suppliers, machinery, capital, etc. which also constitute strengths or weaknesses in the company. The traditional approach of Porter (1981) considers as resources only the strengths that the company can use to formulate and implement its strategies. 
Barney (1991) mentions in a general way that resources are all assets, organizational processes, attributes, information and knowledge controlled by a company, thus allowing the implementation of strategies that improve their efficiency and effectiveness.

Amit and Schoemaker (1993) agree with Cuervo (1993) when pointing out that resources are a "stock" or inventory of available factors that the company owns or controls. Cuervo (1993) adds that these factors (resources) are diverse in nature and include both physical, technological, human and organizational factors.

Regarding the classification of resources Barney (1991) states that they can be grouped into three categories:

1 Physical capital resources: this category includes equipment and technology, the company's infrastructure, geographic location and the degree of accessibility to raw materials.

2 Human capital resources: groups everything related to the workers and managers of the company, such as experience, labor relations, etc.

3 Organizational resources: groups the organizational structure of the company, the planning, control and coordination systems, as well as the informal relations between different groups of the company.

And according to their degree of mobility in the market, they are classified as: marketable resources and non-marketable resources. For his part, Grant (2004) distinguishes between tangible, intangible and human resources. Although this classification is currently accepted only as tangible and intangible resources. Tangible resources include all the physical resources of the company such as: the location of the plant, the infrastructure, the machinery, the building, etc. Financial resources are also included such as: internal financial funds and borrowing capacity.
Intangible resources include those based on information and knowledge such as: human, technological, organizational and commercial culture (patents, trademarks, copyrights, contracts, trade secrets, reputation, business relationships with suppliers and distributors, etc...)

For Cuervo (1993: 68), capacities are "knowledge and skills that arise from the collective learning of the organization, as a result of the combination of resources and the creation of organizational routines that are developed by information exchange based on the human capital of the company".

Unlike resources, capacities are complex patterns of coordination between people and these with other resources. Grant (1991) states that one capacity arises from an organizational routine or several in interaction. This is that, through certain routines, the company has a memory that allows it to undertake complex activities that involve the solution of technical and organizational problems.

Once the theory of resources and capabilities is contextualized, it is necessary to delimit the concepts of competitive advantage and how it is linked. The following section describes the characteristics, elements and management of this.

\section{The competitive advantage from the perspective of the resource-based approach}

This section begins by contextualizing the competitive advantage. Hill and Gareth (2005) explain that a Competitive Advantage arises when a company generates a higher profitability than the companies in its industry have on average. While a Sustained Competitive Advantage exists only when it is able to maintain said performance above the average of the companies in its industry, for several years.

Within the nature of resources Aaker (1989) states that the way to achieve a sustainable competitive advantage lies in a process of asset management (tangible and intangible) and skills, with the following steps: 
1 Identify those assets and skills that have strategic relevance,

2 Select those that will be relevant for future market needs,

3 Implement programs that allow to develop, extend and protect these assets and abilities.

Having, identifying and exploiting strategic resources in order to develop a strategy that allows competition, based on these resources, causes the company to be interested in identifying, knowing and analyzing the resources and capabilities it possesses, discovering which ones can be considered superior or distinctive (Ordonez, 2003). These resources manage to have the capacity to carry out activities in a superior way to their competitors, obtaining therefore better benefits (Barney, 1991).

Ordonez (2003) states that the study and analysis of strategic resources and capabilities can be carried out from three perspectives:

1. Focused on the organizational knowledge generated by coordinating some specific individual capacities and resources, thus constituting the achievement of a sustainable competitive advantage. This perspective assumes a dynamic and evolutionary nature of resources (Reed and DeFillippi, 1990; Grant, 1991; Amit and Schoemaker, 1993).

2. The strategic basis for the development of a sustainable competitive advantage lies in the resources accumulated internally. This perspective considers resources as a stock (Dierickx and Cool, 1989: 1506).

3. This perspective is considered intermediate from the previous ones and indicates that differential or distinctive competitiveness is the cause of the success of a company's strategy, paying greater attention to organizational resources and capabilities..

Also Hall (1992) proposes as sources of competitive advantage four types of capacity differentials: functional, positional, cultural and regulatory.
The functional and cultural differential is based on skills and abilities, that is, it refers to doing while the positional and regulatory differential are related to the assets owned by the company, this refers to having.

According to the previous approaches, the company must be able to develop new skills on which it can base its strategies. In this way, their dynamism and multiplicity will make imitation by competitors difficult and will increase the company's adaptability to external factors and will ensure long-term competitiveness (Mascarenhas, Baveja, Jamil, 1998).

However, not all authors agree to call strategic resources the drivers of competitive advantage, so what for Wernerfelt (1984) is critical resources, for Barney (1991) they are strategic factors and strategic assets for Amit and Schoemaker (1993) or inputs capable of generating sustainable income for Conner (1991).

Strategic assets are those resources and capabilities that explicitly determine a competitive advantage in the company. It is important to identify the characteristics of these resources and capacities, allowing to know why and what these strategic assets are (Cruz, 2002).

However, the above, Barney (1991); Grant (1991); Schoemaker (1992); Amit and Schoemaker (1993) and Peteraf (1993) agree by stating some of the requirements that resources must have to be strategic:

a. Valuable: they must contribute significantly to the achievement of competitive advantage.

b. Scarce and lasting: not being possessed by current or potential competition, otherwise they would cease to be valuable.

c. Difficult to imitate, non-substitutable and non-marketable: this will allow to maintain a long-term competitive advantage.

As a result of the combination of the above characteristics, the income generated by these strategic assets must be appropriable by the company, so that they must be resources over which the company exercises its ownership and control (Cruz, 2002). 
In addition to the requirements mentioned above, in order for the competitive advantage to be sustainable, strategic resources must meet other conditions.

Peteraf (1993: 180) presents a model in which four basic conditions are established so that the strategic resources of the company generate a competitive advantage: heterogeneity, imperfect mobility, ex ante limits to competition and ex post limits to competition. None of them acts independently, but are directly related to each other and heterogeneity is an essential condition of competitive advantage, that is, without which it could not be achieved or obtained.

According to the previous author, the detail of each condition is as follows:

1 Heterogeneity. This condition assumes that the differences between the results achieved by companies of the same industry originate from the different levels of efficiency achieved by the heterogeneous resources of the companies. Those companies that possess a combination of resources and capabilities superior to other companies will also obtain superior results. This condition is based on the scarcity of superior resources by companies, that is, some companies have valuable and scarce resources that are not available or available to rival companies (Barney, 1991). In addition, these superior resources must also be durable, otherwise they will allow for a temporary or shortterm competitive advantage (Amit and Schoemaker, 1993).

2 Imperfect mobility. This condition admits that these resources cannot be marketed in the market due to their particular characteristics or idiosyncrasy, becoming obsolete or lacking use outside the company where they were originally generated. On the contrary, imperfect immobility admits that these resources can be commercialized, although their value within the company that uses them is greater than the value they would have in another company. This means that these resources are adapted to the specific needs of the company.
3 Ex ante limits to competition. These limits that are established before the competition allow a company to enjoy a privileged position with respect to a resource, even before rival companies compete for that resource. The control exercised over a scarce and valuable resource can be translated into economic benefits only if competitors have failed to recognize in advance the value of that resource or are unable to exploit it in such a profitable way because they lack the necessary complementary resources (Grant , 1991).

4 Ex post limits to competition. In order to obtain a competitive advantage and maintain it for a long time, the company must establish ex post limits to the competition, which delay, lead or prevent these established ones from imitating or overcoming the competitive position of the most profitable companies. These are barriers that are established to avoid the imitation of the competitive advantage of a company, whose overcoming involves for the imitators a high cost that could completely reduce the income potentially obtained in said attempt (Fernández, Montes and Vázquez, 1997).

Therefore, obtaining a competitive advantage is due to the possession of strategic assets and the distinctive competencies that allow these resources to be used effectively (Cruz, 2002).

In order for the competitive advantage to be sustainable it is necessary that two requirements be presented: heterogeneity and imperfect mobility that at the same time explain the differences in the economic results of the companies, but are not the only requirements, these must also be difficult to imitate and replace so that the competitive advantage can be sustained for a long time (Lippman and Rumelt, 1982; Barney, 1986a and 1986b; Dierickx and Cool, 1989).

Another necessary condition for the competitive advantage to be lasting is that ex post limits to competition must be established. These conditions are called isolation barriers, entry barriers or barriers to strategic groups (Caves and Porter, 1977). 
These mechanisms act as obstacles to the possible imitation of resources, causing the scope of competitive advantage to competitors in the industry to have a high cost that dissipates the potential income that would be obtained in the attempt.

\section{Methodology}

The main purpose of the research is to develop an intellectual capital management model for the generation of sustainable competitive advantage through a case study in a beach hotel in the city of Manzanillo Colima.

And as secondary objectives the following were raised:

1. Characterize and delimit the particular attributes of heterogeneity, imperfect mobility, ex ante and ex post limits to competition, of those strategic intangible resources, which directly contribute to the formulation and implementation of the competitive advantage.

2. Develop and propose a strategic intangible management model that, through the application of statistical techniques, allows to know its correlation with the generation of sustainable competitive advantage and the generation of economic benefits.

Therefore, to verify the influence of the selected intangibles as strategic in the generation and sustainability of the competitive advantage of the company and the processes and instruments for its management, the following hypothesis is proposed:

H1 Intangibles considered strategic have positive correlation for the generation and sustainability of the competitive advantage of the company.

The variables to be explained in this research and according to Barney (1991); Grant (1991) and Peteraf (1993) would be: heterogeneity, imperfect mobility, excompetition limits and ex-post competition limits, that is, they are: valuable; scarce and lasting; difficult to imitate, non-substitutable and non-marketable.
Starting from the general objective, a mixed, quantitative and qualitative methodological approach was applied in the present study. And through a quantitative research approach of analytical type, it is intended to know the influence of intangible resources on the factors that allow obtaining and sustaining a competitive advantage in the company.

In the analysis of intangibles, the difficulty is evident due to the lack of information, therefore, qualitative research techniques are the most appropriate. The case study is constituted as a technique of analysis of the processes of measurement and management of intangibles in companies, as well as validation of the criteria for their dissemination Sánchez et al. (1999). In accordance with the above, the methodology for the analysis of the management, control and identification of intangibles proposed in this investigation are the Case Study (Garrigós and Camisón, 2001).

Sánchez et al. (1999) argue that in research related to intangible issues, the use of methodologies with subjective analysis is appropriate, considering the following aspects:

A. The analysis of intangibles is a relatively new topic in companies. This implies the absence of historical data on some variables of interest, hence the objective analysis techniques are not the most appropriate.

B. The knowledge society (mentioned in previous sections) has the characteristic of being changeable, so it is not advisable to use historical data to predict or know future scenarios. In techniques with objective data, scenarios with past conditions are constructed, which is unlikely to be repeated in scenarios within the knowledge society.

C. In most cases the information obtained on intangibles is of a qualitative type, therefore the use of techniques based on quantitative data is not the most appropriate. 
D. On several occasions there are no indicators available to measure the variables related to certain intangibles. This implies considering the experience, information and the vision of "experts" or "key informants" of the companies of great importance for the construction of new indicators.

In a first approach to the objective of the investigation, the independent variables were analyzed through the Case Study.

The use of the analysis of the case studies as a research technique is not new, currently the application of this technique and its applications has been booming. In the $20 \mathrm{~s}$ and $30 \mathrm{~s}$ in the United States of America it was considered as a method of qualitative analysis and close to participatory observation. However, in the 50s and $80 \mathrm{~s}$, interest in the use of this technique decreases to the extent of being considered forgotten (Platt, 1992).

With the publication in 1984 of Yin's book on research with Case Studies, a rebound in interest in the study of this technique begins, with the incorporation of new elements of discussion and novel applications Sánchez et al. (1999). In the literature of organizations Yin (2003) is a point of reference in conducting research using this methodology.

Yin (2003, p. 13) defines Case Studies as "an empirical investigation that studies a contemporary phenomenon within its real context, especially when the boundaries between the phenomenon and the context are not clearly evident" and in which they are used Multiple sources of evidence. In addition, he states that at the time there are issues that begin with "why?" Or "how?", Case studies are the most appropriate research strategy. Some relevant advantages over case studies are pointed out by Kingsley and Bozeman (1997) as a research technique:

The researcher receives a large amount of information about the phenomenon being analyzed.

They can be used in any phase of knowledge of the phenomenon to be analyzed, however, it is convenient to apply it when knowledge is scarce or when it is desired to arrive at an explanatory theory of the studied phenomenon.
- $\quad$ It is considered a useful tool for learning a certain phenomenon.

It is a flexible technique, since it allows the researcher to modify his research procedures throughout the study, as a result of the interaction with who is being investigated.

Atkinson and Shaffir (1998) point out that case studies constitute a type of qualitative empirical research whose main characteristics are:

They are carried out in the field, that is, within organizations.

- It involves the collection of information, using the interview and observation as the main instrument, although information from archives and other sources can also be obtained.

- It links the researcher with people belonging to the world he studies, that is, with managers and employees of organizations.

There are no procedures to be applied rigorously.

In order to increase knowledge about the types of case studies, several authors have been consulted. Thus, we have that Yin (2003) considers four types of case studies existing in the literature of organizations:

A. Descriptive: analyze how certain phenomena occur in an organization, within its real context.

B. Exploratory: its main objective is to become familiar with a situation where there is no fully defined theoretical framework.

C. Illustrative: they show the management practices of the most competitive companies.

D. Explanatory: they try to reveal the causes or the reason of a certain organizational phenomenon. 
Hernández et al., (2004) mention that defining the type of study is extremely important, since that is where the research strategy depends and classifies research in the social area, into four types of case studies:

- Explorations that serve as a basis to visualize the scenarios that the researcher will face and usually precede the other three.

- Descriptions base the correlational investigations, which in turn provide important information to initiate explanatory studies.

Explanatory generate a great sense of understanding and are usually highly structured.

Continuing with other authors who classify the case study, we find that Spicer (1992), states that depending on the main objective of the investigation, case studies can be classified into two groups:

A. Descriptive / exploratory: they mainly try to describe the accounting practices used by companies, and

B. Informative / explanatory: they seek to explain the reasons for the observed practices.

Based on the approaches of Spicer (1992), Yin (2003), Hernández et al. (2004) The type of study shown in this research is descriptive, because it is aimed at responding to how certain events, physical or social events occur.

Abundant on the characteristics of the descriptive cases Gómez and Gutiérrez (1996) set out three fundamental aspects:

1. They start from a theoretical model to study a phenomenon, where a set of hypotheses are structured.

2. The hypotheses are contrasted in a representative sample, taking into account that the data and indicators obtained reliably measure the theoretical variables raised in the hypotheses.

3. Finally, it is statistically analyzed to what extent each hypothesis has been tested.
The "Intellectus Model" (IADE-CIC, 2003) and the "Five Capitals Model" (IADECaja Madrid, 2004) were considered as the basis for the construction of the methodological proposal.

As a starting point for the application of the proposed empirical model, the guidelines for the measurement and dissemination of intangibles proposed by the MERITUM Project (Cañibano et al., 2004) based on the conduct of a set of case studies that were considered let you know in detail how the company is managing its intangibles and subsequently an Exploratory Factor Analysis (AEF) was applied.

The Intellectual Capital Model used as a reference in this research has had some modifications and adjustments that have been possible through the application of a first proposal in hotels in countries such as Spain, Mexico, Dominican Republic and Chile, making it an appropriate model for the hotel sector for the experiences obtained in its first applications.

This model is structured in five components: human capital, organizational capital, technological capital, relational capital and contextual capital. Each of the components is integrated by the following elements:

1. Human Capital (four elements): attitudes, training, skills and structure and nature of the workforce.

2. Organizational Capital (four elements): organizational culture, organizational structure, organizational learning and organizational processes.

3. Technological Capital (two elements): technological endowment oriented to internal operability and technological endowment oriented to commercial functions.

4. Business Relational Capital (four elements): customer relationships, supplier relationships, allied relationships and relationships with competitors.

5. Contextual Capital (four elements): reputation and corporate image, corporate social responsibility, environmental conservation and location. 
From these 18 elements, 89 variables have been defined that explain in an operative way the intangibles that the hotels under study have and finally they are reflected in 106 indicators of intellectual capital.

The information was collected through the survey, applying questionnaires containing questions according to the design of the intellectual capital model described above.

The number of questionnaires applied was decided according to the total number of employees at the operational and managerial level of the hotel studied.

The questions were closed and of an evaluative type, using the "Likert" type scale that was from 1 to 5 , allowing to give a value to each of them, where the value of 1 is equal to totally disagree; 2 equals partially disagree; 3 is equal to neutral; 4 is equal to partially agree and 5 is equal to totally agree.

For the selection of the hotel to be studied, a hotel company from the city of Manzanillo was sought that was between small and medium and allowed the application of the survey to its operational and managerial staff and a suitable business profile for the fulfillment of the objective of the investigation and the empirical test of the hypothesis.

According to the directory of hotels in that city, the general manager of several hotels was contacted. There was a hotel that agreed to the application of the surveys, but for the privacy of the data the name is omitted.

The questionnaires were applied during the months of March, April and May 2019 and were applied according to the work shifts and working days of the employees. During the high holiday season for Holy Week, which was during the days of April 15 to 28, no questionnaire was applied.

The total number of questionnaires applied and valid were 36 , among operational employees in the areas of: kitchen, restaurant, maintenance of rooms and green areas, reception and reservations. In the managerial level the areas of: human resources, finance and general management were included.
With the data collected in the applied questionnaires, they were captured in an Excel database to be able to apply through the SPSS program, an Exploratory Factor Analysis that would allow us to know the relationship between the variables.

\section{Results}

Starting from the main purpose of the research that intends to develop an intellectual capital management model for the generation of sustainable competitive advantage, it was decided to apply the Exploratory Factor Analysis method to reduce the data and find the underlying structure within the wide set of variables. According to Hair et al. (1999), define the factors as homogeneous groups formed with variables that are strongly correlated with each other and independent of the rest.

As described above in the methodological part, in the first stage the theoretical approach of the construct and considering the "Intellectus Model" (IADE-CIC, 2003) and the "Five Capital Model" (IADE-Caja Madrid, 2004), 106 items were considered and once the data reduction was applied through the Exploratory Factor Analysis and considering those elements that had a factor load above .70, 31 items were obtained, as shown in the following table.

\begin{tabular}{|l|}
\hline \multicolumn{1}{|c|}{ Human capital } \\
\hline Attitudes: 4 items \\
\hline Training: 2 items \\
\hline Competencies: 3 items \\
\hline Template structure and nature: 1 items \\
\hline Total items: 10 \\
\hline Organizational Capital \\
\hline Organizational culture: 3 items \\
\hline Organizational structure: 5 items \\
\hline Organizational learning: 3 items \\
\hline Organizational processes: 2 items \\
\hline Total items: 13 \\
\hline Technological Capital \\
\hline Internal technological endowment: 1 items \\
\hline Total items: 1 \\
\hline Relational Capital \\
\hline Relationship with customers: 4 items \\
\hline Total items: 4 \\
\hline Contextual Capital \\
\hline Corporate social responsibility: 1 item \\
\hline Conservation of the environment: 2 items \\
\hline Total items: 3 \\
\hline
\end{tabular}

Table 1 Final version of the model Own Elaboration 
At the end and in a first approach of the intellectual capital management model, it was reduced to 31 items that explain the model.

\section{Conclusions}

In conclusion, the evaluation analysis found that the items of the proposed model show good clarity in relation to the specificity of the concept, when reaching a Global Validity Index above (CVI) of 0.70

For this reason, human capital and organizational capital have a clear weight over the other securities blends, this being a clear reference to start a first model and test it to other organizations

\section{References}

Aaker, D. (1989). Managing, assets and skills: the key to a sustainable competitive advantage. California Management Review. 31 (2), 91-106.

Amit, R. y Schoemaker, P. J. H. (1993). Strategic assets and organizational rent. Strategic Management Journal. 14(1), 33-46.

Andrews, K. (1987). The concept of corporate strategy. Illinois: Editorial Irwin

Barney, J. B. (1986). Types of competition and the theory of strategic: toward an integrative framework. Academy of Management Review. 11(4), 791-800.

Barney, J. B. (1986). Strategic factor markets: expectations, luck and business strategy. Management Science. 32(10), 1231-1241.

Barney, J. B. (1991). Firm resources and sustained competitive advantage. Journal of Management. 17(1), 99-120.

Barney, J. B. (1991). Looking inside for competitive advantage. The Academy of Management Executive. 9(4), 49-61.

Bell, D. (1976). El advenimiento de la sociedad postindustrial. Un intento de prognosis social. Madrid: Alianza Universidad.

Bueno, E. (1998). El Capital intangible como clave estratégica en la competencia actual. Boletín de Estudios Económicos. 53(164), 207229.
Cañibano, L.; García-Ayuso, M. y Sánchez, P. (1999). La Relevancia de los intangibles para la valoración y la gestión de empresas: revisión de la literatura. Revista Española de Financiación y Contabilidad de AECA. 100, 17-88.

Cañibano, L.; Sánchez, P.; García-Ayuso, M. y Chaminade, C. (2004). Directrices para la Gestión y Difusión de Información sobre Intangibles (Informe de Capital Intelectual). En L. Cañibano y M. P. Sánchez (ed.), Lecturas sobre Intangibles y Capital Intelectual, AECA, Madrid, 237-273.

Caves, R. y Porter, M. (1977). From entry barriers to mobility barriers: conjectural decisions and contrived deterrence to new competition. Quarterly Journal of Economics, 91(2), 241-262.

Cool, K. y Schendel, D. (1988). Performance differences among strategic group member. Strategic Management Journal. 9(3), 207-223.

Conner, K. R. (1991). A historical comparison of resource-based theory and five schools of thought within industrial organization economics: do we have a new theory of the firm? Journal of Management. 17(1), 121-154.

Cruz, S. (2002). Los recursos y capacidades como fuente de ventajas competitivas. Quaderns de Treball. 136, 1-41.

Cuervo, A. (1993). El papel de la empresa en la competitividad. Papeles de Economía Española. 56, 363-378.

Dierickx, I. y Cool, K. (1989). Assets stock accumulation and sustainability of competitive advantage. Management Science. 35(12), 15041511.

Fernández, E.; Montes, J. y Vázquez, C. (1997). La teoría de la ventaja competitiva basada en los recursos: síntesis y estructura conceptual. Revista Europea de Dirección y Economía de la Empresa, 6(3), 11-32.

Fernández, Z. (1993). La organización interna como ventaja competitiva para la empresa. Papeles de Economía Española. 56, 178-193. 
Fernández, Z. y Suarez, I. (1996). La estrategia de la empresa desde una perspectiva basada en los recursos. Revista Europea de Dirección y Economía de la Empresa, 5(3), 73-92.

Gallardo, D. (2001). Capital intelectual y gestión del conocimiento: problemática contable. Partida doble, 127, 58-71.

Gallardo, D. y Calamonte del río, F.J. (2002). Consideración de los recursos humanos como activo intangible en la contabilidad. Especial referencia al capital intelectual. INUAF STUDIA, 3, 7-32.

Gallardo, D. y Pérez, E. (2003). El capital humano y su carácter de intangible en el rendimiento empresarial. Trabajo presentado en el Ier. Congreso Internacional y Virtual de Intangibles, Madrid, España, 23-27.

Gallardo, D. y Roldán, R. (2003). Creación de valor a partir de las acciones formativas de capital humano. Análisis particular de Caja España. Capital Humano. 166, 54-64.

Grant, R. M. "The resource-base theory of competitive advantage: implications for strategy formulation". California Management Review, vol. 33, núm. 3, (1991): 114-135.

Grant, R. M. (winter special issue 1996). Toward a knowledge-based theory of the firm. Strategic Management Journal. 17, 109-122.

Grant, R. M (2004). Dirección estratégica: conceptos, técnicas y aplicaciones. Madrid: Civitas.

Hall, R. (1992). The strategic analysis of intangibles resources. Strategic Management Journal. 13(2), 135-144.

Hall, R. (1993). A framework linking intangible resource and capabilities to sustainable competitive advantage. Strategic Management Journal. 14(8), 607-618.

Hill, C. y Gareth, R. J. (2005). Administración estratégica, un enfoque integrado. México: McGraw-Hill Interamericana.

Huselid, M. A. (1995). The impact of human resource management practices on turnover, productivity, and corporate financial performance. Academy of Management Journal. 38(3), 635-672.
IADE-CIC (2003). Modelo Intellectus: medición $y$ gestión del capital intelectual. Madrid: Documentos Intellectus.

IADE-Caja Madrid (2004). Modelo de capital intelectual del grupo Caja Madrid: el modelo de los cinco capitales. Madrid.

Lane, R. (1966). The decline of politics and ideology in a knowledgeable society. American Sociological Review. 31(5), 649-662.

Lippman, S. y Rumelt, R. (1982). Uncertain imitability: an analysis of interfirm differences in efficiency under competition. Bell Journal of Economics. 13(2), 418-438.

Mahoney, J. y Pandian, J. R. (1992). The resource-based view within the conversation of strategic management. Strategic Management Journal. 13(5), 363-380.

Mascarenhas, B.; Baveja, A. y Jamil, M. (1998). Dynamics of core competences in leading multinational companies. California Management Journal. 40(4), 117-132.

Nelson, R. y Winter, S. (1996). An evolutionary theory of economic change. Cambridge: Harvard University Press.

Nonaka, I. y Takeouchi, H. (1995). The knowledge-creating company. New York: Oxford University Press.

Ordóñez, P. (2003). Marco conceptual para el análisis del conocimiento organizativo: interrelaciones estratégicas entre teoría de recursos y capacidades y teoría de la empresa basada en el conocimiento. Revista Alta Dirección, 39(230), 17-25.

Ordóñez, P. (2005). Gestión estratégica de recursos humanos, flexibilidad organizativa y encaje estratégico: implicaciones para la competitividad empresarial. Revista ICADE. 65, 31-74.

Platt, J. (1992). Case study in American methodological thought. Current sociology, 40(1), 17-48

Pennings, J. M.; Lee, K. y Van Witteloostuijn, A. (1998). Human capital, social capital and firm dissolution. Academy of Management Journal. 41(4), 425-440.

LINO-GAMIÑO, Juan Alfredo, BARRAGÁN-VÁZQUEZ, Carlos Hugo, LÓPEZ-JIMÉNEZ, Sergio Felipe and CHANG MUÑOZ, Eduardo. Intellectual Capital Management Model for Competitiveness in a Beach Hotel: Case Study in the City of Manzanillo, Colima. Journal of Microfinance Planning and Control. 2019 
Penrose, E. (1962). Teoría del crecimiento de la empresa. Madrid: Editorial Aguilar.

Peteraf, M. A. (1993). The cornerstone of competitive advantage: a resource base-view. Strategic Management Journal. 14(3), 179-191.

Porter, M. (1980). Competitive strategy. Techniques for analyzing industries and competitors. New York: Free Press.

Porter, M. (1985). Competitive advantage. Creating and sustaining superior performance. New York: Free Press.

Raich, M. (2000). Prepararse para la Economía basada en el Conocimiento. Harvard Deusto Business Review, 94, 28-33.

Reed, R. y DeFillippi, R. (1990). Casual ambiguity, barriers to imitation and sustainable competitive advantage. Academy of Management Review, 15(1), 88-102.

Rumelt, R. P. "How much does industry matter?" Strategic Management Journal, vol. 12(3), (1991): 167-185.

Sánchez, P.; Chaminade, C.; Escobar, C. (1999). En busca de una teoría sobre la medición y gestión de los intangibles en la empresa: una aproximación metodológica. Revista Ekonomiaz, 45, 188-213.

Schoemaker, P. (1992). How to link strategic vision to core capabilities. Sloan Management Review. 34(1), 67-81.

Teece, D.; Pisano, G. y Shuen, A. (1997). Dynamic capabilities and strategic management. Strategic Management Journal. 18(7), 509-533.

Wernerfelt, B. (1984). A resource based view of the firm". Strategic Management Journal, 5(2), 171-180.

Yin, R. (2003); “Case study research: design and methods", Sage Publications: California. 